\title{
FAN FICTION E PARÓDIA: UMA TENTATIVA DE VIABILIZAÇÃO DA PRODUÇÃO DE FÃS EM MEIO À AUSÊNCIA DE REFORMA DA LEI DE DIREITOS AUTORAIS
}

\author{
FAN FICTION AND PARODY: \\ ENABLING FAN WORKS AMIDST THE ABSENCE OF A COPYRIGHT LAW \\ REFORMATION
}

\begin{abstract}
FAN FICTION Y PARODIA:
UN INTENTO PARA VIABILIZAR LA PRODUCCIÓN DE FANS FRENTE A LA AUSENCIA DE REFORMA DE LA LEY DE DERECHOS AUTORALES
\end{abstract}

\begin{abstract}
ana Paula Camelo
https://orcid.org/0000-0001-8707-5811 / http://lattes.cnpq.br/4264807675267479 / ana.camelo@fgv.br Doutora em Política Científica e Tecnológica pela UNICAMP. Pesquisadora do Grupo de Ensino e Pesquisa em Inovação da Escola de Direito da Fundação Getúlio Vargas de São Paulo (FGV Direito SP) e do Grupo de Estudos Interdisciplinares em Ciência e Tecnologia da UNICAMP. Campinas, SP, Brasil.

CARLOS Augusto LiguORI FiLHO

https://orcid.org/0000-0002-5943-8408 / http://lattes.cnpq.br/4345722992727793 / carlos.liguori@fgv.br

Doutorando em Filosofia e Teoria Geral do Direito pela Universidade de São Paulo. Mestre em Direito e Desenvolvimento pela FGV Direito SP. Coordenador de projetos e pesquisador do Grupo de Ensino e Pesquisa em Inovação da Escola de Direito da Fundação Getúlio Vargas de São Paulo (FGV Direito SP). São Paulo, SP, Brasil.

\section{RESUMO}

O presente artigo busca descrever e analisar o popular fenômeno da fan fiction frente ao direito autoral brasileiro. Fan fiction consiste em uma forma de produção literária produzida por fãs, que utilizam-se de elementos de histórias originais, como personagens e cenários, para a elaboração de uma obra nova, que é compartilhada livremente entre fãs por meio de plataformas online. Por causa de sua composição, este tipo de produção é considerada obra derivada pela atual lei de direitos autorais, modalidade que exige autorização do detentor dos direitos da obra original, sob pena de violação de direito autoral. A lei, no entanto, prevê algumas situações em que esta autorização não é necessária, as limitaç̃es ao direito autoral, como é o caso da figura da paródia. Busca-se, então, compreender na doutrina e na jurisprudência o que se entende por paródia para enfim identificar quais categorias de fan fiction poderiam ser enquadradas na limitação, de forma a tentar viabilizar ao menos em parte este tipo de produção cultural frente à ausência de reforma da lei.
\end{abstract}

Palavras-chave: Direito autoral; fan fiction; paródia; produção cultural.

\section{ABSTRACT}

This article aims to describe the popular phenomena of fan fiction and to analyze its viability in relation to the Brazilian copyright law. Fan fictions are literary works produced by fans using elements of original stories, such as characters and scenarios, for the elaboration of a new work. This work is then freely shared among fans through online platforms. Because of its composition, this type of production is considered "derivative work" under the current 
copyright law, something that requires authorization from the copyright holder. The law, however, provides some situations in which the necessity of authorization is not required (called "limitations to copyright"), one of which is "parodies". We then tried to understand what is considered as a "parody" by the literature and Brazilian law cases. Finally, we sought to identify which categories of fan fiction could be framed within the limitation, in order to enable that kind of cultural production amidst the lack of a copyright law reformation.

Keywords: Copyright; fan fiction; parody; cultural production.

\section{RESUMEN}

Este artículo describe y analiza el popular fenómeno de la fan fiction frente al derecho autoral brasileño. La fan fiction consiste en una obra literaria producida por fans que se utilizan de elementos de historias originales, como personajes y escenarios, para la elaboración de una obra nueva, que es compartida libremente entre fans por medio de plataformas online. Por su composición, este tipo de producción se considera obra derivada por la ley de derechos autorales vigente en Brasil, modalidad que exige autorización del poseedor de los derechos de la obra original, bajo pena de violación de derechos de autor. La ley, sin embargo, prevé algunas situaciones en las cuales esta autorización no es necesaria (las llamadas limitaciones al derecho de autor), como es el caso de las parodias. Este trabajo buscó comprender cómo la doctrina y la jurisprudencia tratan de parodias para identificar qué categorías de fan fiction podrían ser encuadradas en la limitación, de modo que permita la creación al menos en parte de este tipo de producción cultural frente a la ausencia de reforma de la ley en cuestión.

Palabras clave: Derechos autorales; fan fiction; parodia; producción cultural.

\section{SUMÁRIO}

INTRODUÇÃO; 1 FAN FICTION: PRODUÇÃO CULTURAL DE FÃS; 1.1 Conceito, dinâmica de produção e compartilhamento; 1.2 Conteúdo: taxonomia da fan fiction; 1.3 Fan fiction e direito autoral; 2 PARÓDIA: CONCEITO E TUTELA LEGAL; 2.10 conceito de paródia; 2.2 Paródia como limitação ao direito autoral; 3 FAN FICTION PODE SER CONSIDERADA PARÓDIA?; 3.1 Categorias que se encaixam na limitação; 3.2 Categorias que não se encaixam na limitação; 3.3 Zona cinzenta: fan fiction como crítica à obra original; CONCLUSÃO; REFERÊNCIAS.

\section{INTRODUÇÃO}

Fan fiction é o nome atribuído às histórias elaboradas por fãs de determinado filme, livro ou série de TV, que utilizam-se de elementos destas obras preexistentes na configuração de uma obra nova. Neste sentido, fãs dão continuação às histórias originais, reescrevem-nas, misturam personagens de histórias distintas, dentre outras coisas. A prática é bastante recorrente no contexto de determinadas comunidades de fãs, e é difundida principalmente por meio de portais online específicos para esta finalidade. Nestes portais, fãs reúnem-se para compartilhar, ler e avaliar histórias e interagir com outros que partilham de seus mesmos interesses.

Ainda que amplamente disseminada e majoritariamente sem finalidade lucrativa ou comercial, a prática suscita diversas questões jurídicas com relação aos direitos autorais. De 
ISSN 1981-3694

(DOI): $10.5902 / 1981369427444$

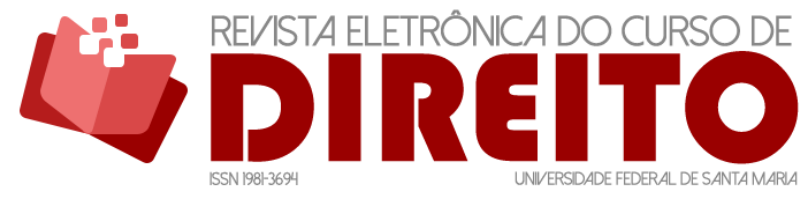

FAN FICTION E PARÓDIA: UMA TENTATIVA DE VIABILIZAÇÃO DA PRODUÇ̃̃O DE FÃS EM MEIO À AUSÊNCIA DE REFORMA DA LEI DE DIREITOS AUTORAIS

ANA PAULA CAMELO CARLOS AUGUSTO LIGUORI FILHO

fato, por utilizar-se de elementos de obras protegidas (como personagens), a fan fiction só seria legal se fosse autorizada pelo detentor dos direitos autorais da obra preexistente. Do contrário, todos os fãs-autores estariam incorrendo em violações ao direito autoral por meio da própria elaboração e compartilhamento de suas histórias.

Isto aponta para uma possível falha no sistema de direitos autorais brasileiro: ainda que uma de suas principais finalidades seja o estímulo à criação intelectual, todo um arcabouço de produção cultural de fãs não apenas não está protegida pelo sistema, como mantém seus autores na ilegalidade. Ainda que a lei preveja determinados casos específicos em que não é necessária a autorização do detentor de direitos autorais para a utilização de obras protegidas, as chamadas limitações ao direito autoral, elas ainda são aparentemente insuficientes para abarcar toda a produção de fãs.

No entanto, a limitação prevista no artigo 47 da Lei de Direitos Autorais (Lei $\mathrm{n}^{\circ}$ 9.610/98) permite a elaboração de paródias de obras preexistentes. A depender do significado de "paródia" estabelecido pela lei, seria possível abarcar diversos tipos distintos de fan fiction, permitindo não apenas que estas histórias não consistam em violação ao direito autoral, mas ainda garantindo a seus autores proteção contra eventuais ações judiciais ou pedidos de remoção de conteúdo elaborados pelos detentores dos direitos autorais das obras originais.

Em meio à ausência de uma reforma da lei de direitos autorais que viabilizasse a produção amadora e sem fins comerciais ou lucrativos, o presente artigo busca: (i) descrever o fenômeno fan fiction, compreendendo sua dinâmica de produção, compartilhamento e os diversos tipos distintos dessas histórias; (ii) analisar a figura da paródia, tanto conceitualmente quanto como limitação ao direito autoral; e (iii) avaliar se e quais tipos de fan fiction poderiam se encaixar dentro desta limitação.

\section{FAN FICTION: PRODUÇÃO CULTURAL DE FÃS}

A partir da segunda metade do século XX, diversas obras culturais, principalmente no campo da literatura e do audiovisual, tornaram-se imensamente populares, movimentando centenas de milhares de pessoas para a frente da televisão, para salas de cinema e livrarias. Jane Becker ${ }^{1}$ aponta que o interesse desta multiplicidade de pessoas por determinadas obras específicas se deu por diversos aspectos distintos, dos quais podemos destacar dois: (i) o alcance

${ }^{1}$ BECKER, Jane $M$. Stories Around the Digital Campfire: Fan Fiction and Copyright Law in the Age of the Internet. In: Connectitcul Public Interest Law Journal, v. 14, n. 1, p. 133-154, 2014. p. 133. 
de determinadas obras a públicos jamais imaginados, proporcionado pelo desenvolvimento de tecnologias de informação e comunicação e pela globalização; e (ii) pela complexidade e imersão narrativa que determinadas obras publicadas a partir deste momento proporcionam aos seus fãs.

Este segundo elemento é particularmente importante para compreensão da chamada “cultura dos fãs". Narrativas como "O Senhor dos Anéis" de J. R. R. Tolkien e "Star Wars" de George Lucas proporcionam aos seus leitores universos que expandem-se para além do mero texto da obra, ensejando intensos debates, discussões e teorias sobre as histórias entre eles. Diversas comunidades de fãs são formadas no entorno destas obras, onde estes interagem entre si de maneiras distintas.

Dentro destas comunidades, fãs interagem a fim de buscarem detalhes escondidos nas obras, compartilharem interpretações alternativas para eventos narrados, conexões com outros universos literários, referências a outros autores e obras, dentre outros aspectos. Cria-se, nas comunidades, uma cultura de debate e compartilhamento de ideias, de modo a preservar por mais tempo o prazer que a leitura (ou consumo) de determinada obra é capaz de gerar para um fã .

Para além de debates e especulações, diversos fãs vão mais além e tomam para si um papel ativo na relação com a sua obra cultural preferida: escrevem histórias, produzem vídeos e fazem desenhos utilizando-se de elementos da narrativa da obra original, como lugares e personagens. Estas verdadeiras “obras derivadas” são subsequentemente compartilhadas dentro da comunidade de fãs, onde são amplamente lidas, assistidas e comentadas. Este tipo de produção cultural é comumente chamada de fan works, dos quais a forma mais popular é a chamada fan fiction ${ }^{3}$.

Neste sentido, esta seção buscará (i) descrever o conceito e a dinâmica de produção e compartilhamento de fan fiction; (ii) entender melhor o conteúdo deste tipo de produção cultural e, por fim, (iii) apontar as eventuais questões jurídicas que autores destas histórias podem enfrentar.

\footnotetext{
2 SCHWABACH, Aaron. Fan Fiction and Copyright: Outsider Works and Intellectual Property Protection. Farnham: Ashgate, 2011. Versão Kindle.

${ }^{3}$ BECKER, Jane M. Stories Around the Digital Campfire: Fan Fiction and Copyright Law in the Age of the Internet. In: Connectitcul Public Interest Law Journal, v. 14, n. 1, p. 133-154, 2014. p. 136.
} 


\subsection{Conceito, dinâmica de produção e compartilhamento}

Não existe consenso acerca da definição do que exatamente poderia ser considerado fan fiction. A maior parte dos autores entendem que este tipo de produção limita-se às obras literárias produzidas pelos fãs, derivadas da obra original, enquanto outros tipos de produções de fãs seriam genericamente chamadas de fan works ${ }^{4}$. Rebecca Tushnet indica que fan fiction seria qualquer tipo de elaboração criativa de história baseada em um segmento da cultura popular identificável, seja ele um filme, um livro, um programa de televisão, uma música, uma peça de teatro, produzindo admiradores da obra que não tem na atividade a sua profissão ${ }^{5}$.

Este tipo de manifestação cultural é algo recorrente desde meados do século passado, e tem suas raízes nas fanzines, revistas independentes, produzidas e editadas por fãs, que tratavam exclusivamente do objeto de fandom e eram distribuídas entre eles ${ }^{6}$. Estas revistas não-oficiais geralmente possuíam baixa circulação e eram restritas ao círculo da fandom, onde cópias eram enviadas a interessados pelo correio, geralmente cobrando-se um pequeno valor para suprir os custos de produção ${ }^{7}$.

Um grande exemplo destas primeiras revistas foi a Spockanalia ${ }^{8}$, fanzine publicada entre 1967 e 1970 especificamente para a comunidade de fãs da primeira série original de Star Trek. As cinco edições produzidas incluíam diversos textos elaborados por fãs, desde análises

\footnotetext{
${ }^{4}$ BECKER, Jane M. Stories Around the Digital Campfire: Fan Fiction and Copyright Law in the Age of the Internet. In: Connectitcul Public Interest Law Journal, v. 14, n. 1, p. 133-154, 2014. p. 133. e MONTANO, Natalie. Hero with a Thousand Copyright Violations: Modern Myth and an Argument for Universally Transformative Fan Fiction. In: Northwestern Journal of Technology and Intellectual Property, v. 11, n. 7, p. 689-705, 2013. p. 689.

Viktor Meyer-Schönberger e Lena Wong, por sua vez, sugerem que existe, além desta, uma definição mais genérica, porém mais abrangente do fenômeno, quase intercambiável com o termo fan works: para eles, qualquer tipo de ficção produzida por fãs que utilize elementos de obras preexistentes pode ser considerada fanfiction. Neste sentido, caso um grupo de amigos grave uma sequência amadora de Star Wars, o filme final será também considerado fanfiction. Em MAYER-SCHÖNBERGER, Viktor; WONG, Lena. Fan or Foe? Fan Fiction, Authorship, and the Fight for Control. In: IDEA - The Intellectual Property Law Review, v. 54, n. 1, 2013. p. 4.

${ }^{5}$ TUSHNET, Rebecca. Legal Fictions: Copyright, Fan Fiction and a New Common Law. In: Loyola of Los Angeles Entertainment Journal, v. 17, n. 3, p. 651-686, 1997. p. 655.

${ }^{6}$ SCHWABACH, Aaron. Fan Fiction and Copyright: Outsider Works and Intellectual Property Protection. Farnham: Ashgate, 2011. Versão Kindle.

${ }^{7}$ CIANFAGLIONE, Natalia. Hollywood Online: Fan Fiction, Copyright and the Internet. Boston University School of Law, 2011. Disponível em: <http://papers.ssrn.com/sol3/papers.cfm?abstract_id=2094179>. Acesso em: 5 set. 2016. p. 3.

8 SPOCKANALIA. Fanlore, 14 abr. 2018. Disponível em: <https://fanlore.org/wiki/Spockanalia>. Acesso em: 20 abr. 2018.
} 
aprofundadas das diversas 'raças' alienígenas retratadas na série, até histórias não-oficiais envolvendo as suas personagens principais, consistindo em aventuras não televisionadas de Spock, Kirk e o resto da tripulação da Enterprise. Evidentemente, a inclusão destas narrativas fez com que a Spockanalia fosse também uma dos veículos percussores na publicação e circulação de fan fiction?.

Devido às restrições da época com relação à produção de cópias e das vias de compartilhamento destas fanzines (majoritariamente entrega de mão em mão e serviços dos correios), seu alcance e repercussão eram bastante limitados ${ }^{10}$. Isso mudou a partir de meados da década de 1990, com a popularização da Internet como meio de comunicação.

Com o advento da Internet, indivíduos puderam compartilhar ideias e obras inteiras, formar comunidades e se comunicar com usuários ao redor do mundo a custos praticamente nulos e sem a demora de tradicionais meios de comunicação, como o serviço postal ${ }^{11}$. A Internet facilitou a formação de comunidades de fãs de maior porte, visto que as distâncias físicas para a comunicação foram desfeitas, bem como permitiu maior disseminação dos materiais produzidos $^{12}$.

Hoje em dia, há inúmeras plataformas online que se dedicam exclusivamente à hospedagem de fan fiction e à interação de fãs. Nestes portais, é comum não apenas o compartilhamento de fan fiction entre fãs, mas também contam com equipes próprias para revisão gramatical das histórias já compartilhadas ${ }^{13}$, espaços para discussão e avaliação das narrativas ${ }^{14}$ e até mesmo premiações para as histórias mais bem avaliadas pelos leitores ${ }^{15}$.

\footnotetext{
${ }^{9}$ CIANFAGLIONE, Natalia. Hollywood Online: Fan Fiction, Copyright and the Internet. Boston University School of Law, 2011. Disponível em: <http://papers.ssrn.com/sol3/papers.cfm?abstract_id=2094179>. Acesso em: 5 set. 2016. p. 4.

10 HELLEKSON, Helen; BUSSE, Kristina (Org.). Fan Fiction and Fan Communities in the Age of the Internet: New Essays. Jefferson: McFarland, 2006. Versão Kindle.

${ }^{11}$ BECKER, Jane M. Stories Around the Digital Campfire: Fan Fiction and Copyright Law in the Age of the Internet. In: Connectitcul Public Interest Law Journal, v. 14, n. 1, p. 133-154, 2014. p. 134.

12 HELLEKSON, Helen; BUSSE, Kristina (Org.). Fan Fiction and Fan Communities in the Age of the Internet: New Essays. Jefferson: McFarland, 2006. Versão Kindle.

13 É comum, em grandes plataformas de compartilhamento de fan fiction, a existência de um grupo de usuários chamados de beta readers. Beta readers são usuários responsáveis pela revisão dos textos encaminhados por autores às plataformas eletrônicas. Na maioria dos casos, os betas são usuários experientes que dedicam parte do seu tempo na plataforma revisando trabalhos de autores com menos experiência. Essa revisão pode consistir desde a correção de erros gramaticais até recomendações de técnicas de redação, coesão textual, apontamento de inconsistências da história, dentre outras coisas.

${ }^{14}$ Alguns portais permitem com que usuários escrevam resenhas avaliando a qualidade das fan fiction lá disponibilizadas. Além disso, é comum possuírem fóruns de discussão para a interação e debate entre fãs.

$15 \mathrm{O}$ portal de fan fiction brasileiro Fanfic Obsession, por exemplo, estabelece um ranking mensal das histórias mais bem avaliadas por seus usuários. A lista fica disponível logo na homepage do portal $<$ http://fanficobsession.com.br/>.
} 
As comunidades virtuais de fan fiction são amplamente erguidas em torno de uma cultura participativa, no sentido de que todos os seus atores podem ter papéis ativos dentro da comunidade: autores podem ser leitores; leitores podem ser revisores; revisores podem ser críticos, etc. Para se ter uma ideia da popularidade deste tipo de portal, é elucidativo o exemplo da plataforma Fanfiction.net, que sozinha conta com quase três milhões de usuários ${ }^{16}$ ao redor do mundo e mais de 740 mil fan fictions só da saga Harry Potter ${ }^{17}$.

Apesar da imensa popularidade deste tipo de plataforma e da abrangência e complexidade de grandes portais de compartilhamento, o objetivo da produção de fan fiction é ainda muito simples: demonstrar o amor que o leitor sente pela obra original. Comunidades online de fãs viabilizam a ânsia de seus usuários em discutir, explorar, criticar e celebrar entre si estas obras para eles tão importantes. Estes autores amadores são estimulados a criar por este motivo, e é por isso que a fan fiction é compartilhada de forma gratuita e não tem fins comerciais e lucrativos $^{18}$. Além disto, o cadastramento nestes portais é inteiramente gratuito, assim como todos os outros serviços oferecidos por eles, como a revisão gramatical das histórias, que é inteiramente realizada por usuários voluntários ${ }^{19}$.

\subsection{Conteúdo: taxonomia da fan fiction}

Para além da dinâmica das comunidades, o conteúdo das fan fictions também é muito importante para melhor compreensão do fenômeno. Já foi dito no presente artigo que produção de fan fiction envolve o empréstimo de elementos da obra original (como personagens e cenários) para a criação de uma nova história. Esta simples dinâmica abre espaço para a criação de inúmeros tipos de histórias distintas.

\footnotetext{
16 Este era o número estimado de usuários do portal no ano de 2011. SENDLOR, Charles. Fan Fiction Demographics in 2010: Age, Sex, Country. 18 mar. 2011. Disponível em: <http://ffnresearch.blogspot.com.br/2011/03/fan-fiction-demographics-in-2010-age.html>. Acesso em: 30 ago. 2016.

${ }^{17}$ Nesta mesma plataforma, a segunda saga com o maior número de fan fiction é o mangá/anime Naruto, com cerca de 405 mil histórias, como é possível ver em: <https://www.fanfiction.net/book/HarryPotter/> e <https://www.fanfiction.net/anime/>. Acesso em: 30 ago. 2016.

${ }_{18}$ MONTANO, Natalie. Hero with a Thousand Copyright Violations: Modern Myth and an Argument for Universally Transformative Fan Fiction. In: Northwestern Journal of Technology and Intellectual Property, v. 11, n. 7, p. 689-705, 2013. p. 693.

${ }^{19} \mathrm{O}$ serviço de beta reader, descrito na nota 3, é inteiramente realizado por internautas voluntários. Cf. 0 QUE é um beta beader? Nyah! Fanfiction, 21 set. 2017. Disponível em: <https://fanfiction.com.br/pagina/30/0_que_e_um_beta_reader/>. Acesso em: 30 ago. 2016.
} 
No que tange ao seu conteúdo, estas histórias podem ser categorizadas de incontáveis maneiras distintas, das quais se sugere quatro grupos distintos, os dois primeiros referentes à relação entre a fan fiction e a obra original e os seguintes relativos ao gênero da narrativa:

(i) Com relação à continuidade: dentro desta categoria, analisa-se a relação da fan fiction com a linha do tempo da obra original: a história dá continuidade à narrativa oficial? Ela acontece em paralelo a algum evento da obra original? Ela busca revisitar e reescrever algum momento da obra original?

(ii) Com relação ao universo em que se passa a história: Toda e qualquer fan fiction ocorre dentro de um universo específico. Tal universo não se caracteriza só pela presença ou não de personagens de uma saga, mas também pela inclusão de diversos elementos específicos do microcosmo estabelecido pela história original. Uma fan fiction ocorre dentro do "universo original" quando os únicos elementos modificados ou criados consistem em situações e atos que não acontecem na obra original; quando há alguma modificação significativa ou inclusão de elementos estranhos ao material oficial na narrativa, por exemplo, uma história em que Harry Potter é o vilão, diz-se configurar um “universo alternativo”. Por fim, há ainda o "universo compartilhado", que consiste em histórias centradas na interação entre personagens de obras distintas, por exemplo, no encontro de Luke Skywalker (de Star Wars) com Frodo Bolseiro (de Senhor dos Anéis).

(ii) Com relação ao gênero da narrativa na taxonomia tradicional: Esta divisão é bem mais simples, e tem como base para classificação os gêneros comuns de narrativas tradicionais, como “comédia”, “drama”, “terror”, “erótico”, etc.

(iv) Com relação aos gêneros específicos à cultura de fan fiction: Como bem aponta Jane Becker, há ainda diversos gêneros específicos à cultura de fan fiction que não possuem contrapartes na narrativa tradicional ${ }^{20}$. Estes gêneros são inúmeros, sendo os mais populares aqueles que indicam o tipo de romance de que a trama trata (a produção de fan fiction erótica e de romance são uma prática comum nas comunidades): “het" são romances heterossexuais e "slash" são romances homossexuais. Nesta chave, se a história não trata de romance, é chamada de "gen" ou "general fiction"21.

\footnotetext{
${ }^{20}$ BECKER, Jane M. Stories Around the Digital Campfire: Fan Fiction and Copyright Law in the Age of the Internet. In: Connectitcul Public Interest Law Journal, v. 14, n. 1, p. 133-154, 2014. p. 136.

${ }^{21}$ A Fanlore, wiki dedicada exclusivamente à cultura de fãs, é uma excelente fonte para compreender pormenorizadamente as particularidades de cada um destes gêneros. GENRE. Fanlore, 27 jul. 2017. Disponível em: <https://fanlore.org/wiki/Genre>. Acesso em: 31 ago. 2016.
} 
Uma categoria à parte, porém de extrema relevância para a boa compreensão do fenômeno fan fiction, são as chamadas histórias de "Mary Sue". Usado de forma pejorativa dentro das comunidades de fãs, "Mary Sue" é o nome genérico de uma personagem que protagoniza este tipo de história, personagem esta original, não extraída de nenhuma outra obra. Essas personagens geralmente consistem em uma espécie de inserção do próprio autor dentro de sua história através da criação de um alter ego. Neste sentido, é comum que os autores se retratem sem nenhum defeito aparente, criado como uma figura idealizada e, muitas vezes, caricata, o que muitas vezes pode atrapalhar o desenvolvimento de conflitos e o andamento da história.

Porém, como apontam Anupam Chander e Madhavi Sunder, a figura da "Mary Sue" também é usada para finalidades não narcisistas: a ferramenta pode servir como uma crítica à obra original $^{22}$. Por exemplo, a inserção de uma personagem feminina como a grande heroína de uma história como Senhor dos Anéis é uma forma de criticar a falta de diversidade da série e empoderar fãs que, apesar do amor à saga, não se sentem representados por elas.

Com esta breve descrição de elementos principais do fenômeno fan fiction, é possível compreender o grau de engajamento, a popularidade e a complexidade das comunidades e produções de fãs. Apesar disto, pelo fato destes fãs utilizarem componentes de obras intelectuais protegidas em suas histórias, estariam eles cometendo algum tipo de ilegalidade ao escrevê-las e compartilhá-las online?

\subsection{Fan fiction e direito autoral}

Um aspecto fundamental das obras de fan fiction é a utilização de elementos, como personagens, cenários e referências, de obras preexistentes em uma obra nova. Poderia alegarse que a utilização destes elementos configuraria reprodução (cópia) parcial da obra original, mas como os elementos emprestados são utilizados de forma a compor algo totalmente novo, é mais coerente entendê-las como obras derivadas. Esta reconfiguração dos elementos da obra original afasta a possibilidade de considerar fan fiction como reprodução da obra original.

22 CHANDER, Anupam; SUNDER, Madhavi. Everyone's a Superhero: A Cultural Theory of "Mary Sue" Fan Fiction as Fair Use. In: California Law Review, v. 95, p. 597-626, 2007. Disponível em: <http://scholarship.law. berkeley.edu/cgi/viewcontent. cgi?article=1228\&context=californialawreview $>$. Acesso em: 6 set. 2016. 
Sob a ótica da Lei de Direitos Autorais brasileira (LDA), Lei $\mathrm{n}^{\circ} 9.610 / 98$, este tipo de produção é considerada como obra derivada ${ }^{23}$, pelo fato desta consistir em uma transformação da obra primígena, utilizando e rearranjando diversos de seus elementos. Este tipo de utilização da obra original necessita, via de regra, da autorização do detentor dos direitos autorais relativos a esta obra ${ }^{24}$. Uma utilização sem esta autorização consiste, portanto, em uma violação ao direito autoral, podendo os fãs/autores ser responsabilizados.

Para além das violações relativas ao conteúdo das obras de fan fiction em si, fãs também podem ser responsabilizados pelo compartilhamento de suas histórias nas plataformas online, uma vez que a sua distribuição também depende de autorização do detentor dos direitos autorais da obra originária ${ }^{25}$.

Além disto, a LDA prevê um conjunto de direitos garantidos ao autor da obra original, direitos estes que vinculam a obra intimamente à personalidade do autor; são os chamados "direitos morais do autor”. Esta figura pretende assegurar a relação pessoal existente entre autor e obra, sendo os direitos morais inalienáveis, irrenunciáveis e intransferíveis. A lei estabelece um rol de sete direitos morais do autor, sendo um deles o direito de assegurar a

\footnotetext{
23 “Art. $5^{\circ}$ Para os efeitos desta Lei, considera-se: (...)

VIII - obra: (...)

g) derivada - a que, constituindo criação intelectual nova, resulta da transformação de obra originária;(...)"

BRASIL. Lei no 9.610, de 19 de fevereiro de 1998. Altera, atualiza e consolida a legislação sobre direitos autorais e dá outras providências. Diário Oficial da República Federativa do Brasil, Brasília, 20 fev. 1998. Disponível em: <http://www.planalto.gov.br/ccivil_03/leis/L9610.htm>. Acesso em: 10 jan. 2017.

24 “Art. 29. Depende de autorização prévia e expressa do autor a utilização da obra, por quaisquer modalidades, tais como: (...)

III - a adaptação, o arranjo musical e quaisquer outras transformações; (...)"

BRASIL. Lei ${ }^{\circ}$ 9.610, de 19 de fevereiro de 1998. Altera, atualiza e consolida a legislação sobre direitos autorais e dá outras providências. Diário Oficial da República Federativa do Brasil, Brasília, 20 fev. 1998. Disponível em: <http://www.planalto.gov.br/ccivil_03/leis/L9610.htm>. Acesso em: 10 jan. 2017.

25 “Art. 29. Depende de autorização prévia e expressa do autor a utilização da obra, por quaisquer modalidades, tais como: (...)

VII - a distribuição para oferta de obras ou produções mediante cabo, fibra ótica, satélite, ondas ou qualquer outro sistema que permita ao usuário realizar a seleção da obra ou produção para percebê-la em um tempo e lugar previamente determinados por quem formula a demanda, e nos casos em que o acesso às obras ou produções se faça por qualquer sistema que importe em pagamento pelo usuário;(...)"

BRASIL. Lei $n^{\circ}$ 9.610, de 19 de fevereiro de 1998. Altera, atualiza e consolida a legislação sobre direitos autorais e dá outras providências. Diário Oficial da República Federativa do Brasil, Brasília, 20 fev. 1998. Disponível em: <http://www.planalto.gov.br/ccivil_03/leis/L9610.htm>. Acesso em: 10 jan. 2017.
} 
integridade da obra ${ }^{26}$. Neste sentido, a ausência de autorização para produção da obra derivada poderia configurar também violação a este direito moral do autor.

A possibilidade de responsabilização destes fãs por violação aos direitos autorais é algo que assombra as comunidades de fan fiction não apenas no Brasil, como também ao redor do mundo. Esta era uma questão que, até o surgimento da Internet comercial na década de 1990, não possuía grande relevância pela inviabilidade da disseminação da fan fiction para a maioria dos autores e detentores de direitos autorais. Com a crescente popularização dos portais de compartilhamento destas histórias, este tipo de produção cultural cada vez mais se aproxima dos holofotes de grandes detentores de direito autoral, deixando os fãs à mercê da aplicação da lei.

Algumas dúvidas podem surgir: o fato de estas obras não possuírem finalidade comercial nem lucrativa não as isentariam de eventuais sanções relativas ao direito autoral? Não há nada no sistema normativo que viabilize a produção cultural amadora? 0 direito autoral é absoluto?

De forma a equilibrar os interesses dos autores com relação à proteção de suas obras, e o interesse da sociedade em acessar e utilizar estas obras culturais, o legislador optou por incluir na LDA uma série de mecanismos que viabilizassem esta intenção: as chamadas limitações ao direito autoral, previstas no Capítulo IV da lei, composto dos artigos 46, 47 e 48. Elas consistem em uma lista taxativa de situações em que obras protegidas podem ser utilizadas sem que seja necessária a autorização do detentor dos direitos autorais.

Ao todo, a lei estabelece treze situações em que a utilização da obra é livre. Pedro Mizukami et al sugerem que estas limitações podem ser divididas em três grupos distintos: 1. Utilizações livres referentes à reprodução total ou parcial da obra; 2. Utilizações livres referentes à produção de obras derivadas; e 3. Utilizações referentes à execução de obras ${ }^{27}$.

Como apontado no início deste item, uma possível defesa da produção de fan fiction seria relativa à produção de obras derivadas, pelo simples fato de que esta se enquadra na figura da obra derivada. Dentro desta categoria, Mizukami et $\mathrm{al}^{28}$ aponta que a lei prevê duas

26 “Art. 24. São direitos morais do autor: (...)

IV - o de assegurar a integridade da obra, opondo-se a quaisquer modificações ou à prática de atos que, de qualquer forma, possam prejudicá-la ou atingi-lo, como autor, em sua reputação ou honra; (...)"BRASIL. Lei $\mathrm{n}^{\circ}$ 9.610, de 19 de fevereiro de 1998. Altera, atualiza e consolida a legislação sobre direitos autorais e dá outras providências. Diário Oficial da República Federativa do Brasil, Brasília, 20 fev. 1998. Disponível em: <http://www.planalto.gov.br/ccivil_03/leis/L9610.htm>. Acesso em: 10 jan. 2017.

${ }^{27}$ MIZUKAMI, Pedro; LEMOS, Ronaldo; MAGRANI, Bruno; SOUZA, Carlos Affonso Pereira de. Exceptions and Limitations to Copyright in Brazil: A Call for Reform. In: SHAVER, Lea. Access to Knowledge in Brazil: New Research on Intellectual Property, Innovation and Development. New Haven: Information Society Project, 2010. p. 78.

${ }^{28}$ MIZUKAMI, Pedro; LEMOS, Ronaldo; MAGRANI, Bruno; SOUZA, Carlos Affonso Pereira de. Exceptions and Limitations to Copyright in Brazil: A Call for Reform. In: SHAVER, Lea. Access to Knowledge in Brazil: 
limitações específicas: a limitação relativa à produção de paráfrases e paródias ${ }^{29}$ e a limitação relativa à produção de obras derivadas de obras localizadas em logradouro público ${ }^{30}$, como obras arquitetônicas, monumentos, grafites, etc.

Deixando de lado a segunda categoria de limitação, que foge por completo do objeto do presente artigo, seria possivel alegar que a fan fiction configura uma espécie de paródia da obra original? Poderia a limitação prevista no artigo 47 da LDA colocar os fãs-autores dentro da legalidade? Quais são os conceitos e limites da paródia para o direito autoral brasileiro? Estas são questões a serem respondidas a seguir.

\section{PARÓDIA: CONCEITO E TUTELA LEGAL}

A figura da paródia é uma das mais curiosas do direito autoral brasileiro. Ela está prevista no artigo 47 da LDA, que lê "São livres as paráfrases e paródias que não forem verdadeiras reproduções da obra originária nem the implicarem descrédito" 31 . 0 que o artigo quer dizer é que a produção de paródias independe de autorização do detentor dos direitos da obra original. Esta limitação é curiosa, porque, ao contrário de diversas outras previstas na lei, ela não exige expressamente que a utilização não tenha fins lucrativos ou comerciais ${ }^{32}$. Neste

New Research on Intellectual Property, Innovation and Development. New Haven: Information Society Project, 2010. p. 84.

29 “Art. 47. São livres as paráfrases e paródias que não forem verdadeiras reproduções da obra originária nem the implicarem descrédito."

BRASIL. Lei $\mathrm{n}^{\circ}$ 9.610, de 19 de fevereiro de 1998. Altera, atualiza e consolida a legislação sobre direitos autorais e dá outras providências. Diário Oficial da República Federativa do Brasil, Brasília, 20 fev. 1998. Disponível em: <http://www.planalto.gov.br/ccivil_03/leis/L9610.htm>. Acesso em: 10 jan. 2017.

30 "Art. 48. As obras situadas permanentemente em logradouros públicos podem ser representadas livremente, por meio de pinturas, desenhos, fotografias e procedimentos audiovisuais."

BRASIL. Lei $n^{\circ}$ 9.610, de 19 de fevereiro de 1998. Altera, atualiza e consolida a legislação sobre direitos autorais e dá outras providências. Diário Oficial da República Federativa do Brasil, Brasília, 20 fev. 1998. Disponível em: <http://www.planalto.gov.br/ccivil_03/leis/L9610.htm>. Acesso em: 10 jan. 2017.

31 BRASIL. Lei $n^{\circ}$ 9.610, de 19 de fevereiro de 1998. Altera, atualiza e consolida a legislação sobre direitos autorais e dá outras providências. Diário Oficial da República Federativa do Brasil, Brasília, 20 fev. 1998. Disponível em: <http://www.planalto.gov.br/ccivil_03/leis/L9610.htm>. Acesso em: 10 jan. 2017.

32 A título exemplificativo, podemos apontar duas outras limitações da lei: “II - a reprodução, em um só exemplar de pequenos trechos, para uso privado do copista, desde que feita por este, sem intuito de lucro;" e "Vl - a representação teatral e a execução musical, quando realizadas no recesso familiar ou, para fins exclusivamente didáticos, nos estabelecimentos de ensino, não havendo em qualquer caso intuito de lucro;" (grifos nossos). BRASIL. Lei $n^{\circ}$ 9.610, de 19 de fevereiro de 1998. Altera, atualiza e consolida a legislação sobre direitos autorais e dá outras providências. Diário Oficial da República 
ISSN 1981-3694

(DOI): $10.5902 / 1981369427444$

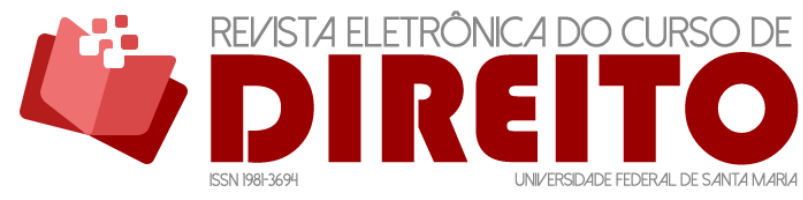

FAN FICTION E PARÓDIA: UMA TENTATIVA DE VIABILIZAÇÃO DA PRODUÇÃO DE FÃS EM MEIO À AUSÊNCIA DE REFORMA DA LEI DE DIREITOS AUTORAIS

ANA PAULA CAMELO CARLOS AUGUSTO LIGUORI FILHO

sentido, seria absolutamente razoável o entendimento de que paródias podem ser comercializadas, o que garante razoável liberdade ao autor da paródia.

Neste sentido, esta figura consta como limitação ao direito autoral desde a primeira Lei Autoral brasileira, no artigo 50 da Lei $\mathrm{n}^{\circ}$ 5.988/73, com exatamente o mesmo texto do dispositivo atual $^{33}$.

O grande problema é que nenhum destes dois diplomas normativos fornece a definição do termo "paródia" e muito menos os requisitos que devem ser preenchidos para que uma obra possa se encaixar dentro do escopo desta limitação. A principal consequência disto é a insegurança jurídica gerada aos autores, que não têm como saber se suas obras se encaixam na limitação, possivelmente arriscando a legalidade de suas obras. Esta ausência de uma descrição detalhada da figura é o primeiro grande desafio a ser superado para avaliar se a produção de fãs pode se encaixar na limitação do artigo 47.

Neste sentido, busca-se a seguir compreender de fato o conceito de "paródia" entre estudiosos do direito e áreas afins e, em seguida, analisar a tutela da paródia como limitação ao direito autoral, tanto nas condições estabelecidas pela lei quanto pela perspectiva da jurisprudência.

\subsection{0 conceito de paródia}

Como bem aponta Priscila Perez, a questão do conceito e escopo da paródia não é frequentemente abordada por estudiosos do direito autoral, com grandes estudos do tema centrando-se fora do direito de autor, focando na relação entre paródias e ofensa à imagem e honra de pessoas parodiadas ${ }^{34}$.

Dentre os estudiosos de direito autoral, Eliane Abrão define "paródia” como "imitação cômica de uma composição literária; a satirização de uma obra dramática ou trágica"35. Para a

\footnotetext{
Federativa do Brasil, Brasília, 20 fev. 1998. Disponível em: <http://www.planalto.gov.br/ccivil_03/leis/L9610.htm>. Acesso em: 10 jan. 2017.

33 "Art. 50. São livres as paráfrases e paródias que não forem verdadeiras reproduções da obra originária, nem the implicarem descrédito." BRASIL. Lei $\mathrm{n}^{\circ}$ 9.610, de 19 de fevereiro de 1998 . Altera, atualiza e consolida a legislação sobre direitos autorais e dá outras providências. Diário Oficial da República Federativa do Brasil, Brasília, 20 fev. 1998. Disponível em: <http://www.planalto.gov.br/ccivil_03/leis/L9610.htm>. Acesso em: 10 jan. 2017.

${ }^{34}$ PEREZ, Priscila de Carvalho Ruiz. Paródia como Violação de Direito Autoral. In: Revista da ABPI, v. 137, jul./ago. $2015 . \quad$ Disponível em: <http://prisciladecarvalhoperez.jusbrasil.com.br/artigos/240522892/parodia-como-violacao-de-direitoautoral>. Acesso em: 6 set. 2016.

${ }^{35}$ ABRÃO, Eliane Y. Direitos de Autor e Direitos Conexos. 2. ed. São Paulo: Migalhas, 2014. p. 357.
} 
autora, portanto, a referência à obra anterior e o caráter cômico seriam as características basilares desta figura. Na mesma linha, Priscila Perez entende que a paródia seria "a imitação burlesca de obra literária alheia, ou a sua deformação num sentido cômico"36, acrescentando que a figura também pode ser aplicada à música.

Michael Chagares também indica que a imitação e o humor seriam os aspectos fundamentais que definiriam uma determinada obra derivada como sendo paródia, afirmando que "paródias são composições artísticas que imitam e ridicularizam a reflexão e o estilo de uma obra original"37.

A finalidade humorística da paródia pode ser encontrada também na própria definição do termo em dicionários da língua portuguesa. O Dicionário Houaiss da Língua Portuguesa, por exemplo, define-a como "obra literária, teatral, musical etc., que imita outra obra, ou os procedimentos de uma corrente artística, ela etc., com objetivo jocoso ou satírico"38. 0 Novo Dicionário Aurélio da Língua Portuguesa sugere duas definições ainda mais simples, sempre com caráter humorístico: “1. imitação cômica de uma composição literária; 2.Imitação burlesca”39.

No entanto, a necessidade de um caráter cômico para a paródia nem sempre é um elemento essencial para aqueles que buscam definir o termo. João Fragoso arrisca:

Paródias são formas de expor a obra, não necessariamente ao ridículo, mas caracterizando um tipo de crítica ou comentário, seja mais ou menos ácido, seja mais ou menos bem humorado, mas sempre estabelecendo em relação à obra um grau de distorção do modo como ela se apresenta originalmente ${ }^{40}$.

Esta definição prioriza um outro elemento importante na configuração de uma paródia: a crítica. Ainda que ausente a comicidade, a paródia deve utilizar-se da obra originária de forma a estabelecer uma crítica ou comentário à obra original. A necessidade da presença de humor, dentro desta caracterização, é relativizada.

\footnotetext{
${ }^{36}$ PEREZ, Priscila de Carvalho Ruiz. Paródia como Violação de Direito Autoral. In: Revista da ABPI, v. 137, jul./ago. 2015. Disponível em: <http://prisciladecarvalhoperez.jusbrasil.com.br/artigos/240522892/parodia-como-violacao-de-direitoautoral>. Acesso em: 6 set. 2016.

37 Tradução nossa. No original, em inglês: "Parodies are artistic compositions which mimic and ridicule the thought and style of an original work". CHAGARES, Michael. Parody or Piracy: The Protective Scope of the Fair Use Defense to Copyright Infringement Actions Regardinf Parodies. In: Columbia-VLA Journal of Law \& the Arts, v. 12, p. 229-248, 1988. p. 229.

${ }^{38}$ HOUAISS, Antônio. Dicionário Houaiss da Língua Portuguesa. Rio de Janeiro: Objetiva, 2012. p. 1437.

${ }^{39}$ FERREIRA, Aurélio B. H. Aurélio século XXI: o dicionário da Língua Portuguesa. 3. ed. Rio de Janeiro: Nova Fronteira, 1999. p. 1272.

${ }^{40}$ FRAGOSO, João Henrique da Rocha. Direito Autoral: Da Antiguidade à Internet. São Paulo: Lumen luris, 2009. p. 327.
} 
No mesmo sentido, José de Oliveira Ascensão define a figura simplesmente como a utilização da obra original de forma original e criativa, acrescentando que a obra primígena “dá só o tema, mas a paródia faz a criação peça por peça de que resulta um novo conjunto; por isso se fala no tratamento antitético do tema" ${ }^{41}$, reiterando o papel crítico à obra original que deve ser imposto à paródia.

Marco Antônio do Anjos aponta, na mesma linha de Ascensão, que é a crítica e subversão da obra anterior que caracterizaria a paródia, e não sua comicidade:

0 que interessa para tipificar essa técnica é a recriação, o ato de transportar uma obra para outra, que a imita mas, de certa forma, a nega. Toda vez que isso ocorrer, haverá paródia.(...)

A idéia de subversão de uma obra, negando-a, é o ponto central da paródia. 0 fato de isso ser muito mais freqüente por meio da transformação de uma criação dramática em humorística não impede outras formas de obras antitéticas, porém em gêneros distintos da comicidade ${ }^{42}$.

Neste sentido, a recriação de uma obra original cômica em uma obra dramática também poderia se encaixar na figura da paródia, conquanto esta sirva como antítese da obra original, negando-a, criticando-a.

Ainda sobre o caráter crítico da figura, Richard Posner sugere que a paródia pode consistir tanto em uma crítica à obra original, como também em uma ferramenta crítica a outra coisa, nada relacionada à obra primígena ${ }^{43}$. Pode-se ilustrar esta segunda definição com um exemplo: uma música popular, como Roda Viva de Chico Buarque, pode ter sua letra modificada de modo a criticar a ação da Polícia Militar em manifestações em São Paulo. Neste sentido, configura-se uma paródia dotada de caráter crítico (independente do humor), mas à instituição da PM, e não à composição do músico.

Fugindo um pouco das definições propostas por estudiosos de direito autoral, a definição de Posner se assemelha àquela proposta pela teórica cultural Linda Hutcheon, que sugere que o cerne fundamental da paródia é a "transcontextualização", entendida como a ressignificação da obra original:

Nada existe em paródia que necessite da inclusão de um conceito de ridículo, como existe, por exemplo, na piada, ou burla, do burlesco. A paródia é, pois, na

\footnotetext{
${ }^{41}$ ASCENSÃO, José de Oliveira. Direito Autoral. São Paulo: Forense, 1980. p. 103.

42 ANJOS, Marco Antônio dos. O Humor: Estudo à luz do direito de autor e da personalidade. Tese (Doutorado em Direito). 133 f. Faculdade de Direito, Universidade de São Paulo, 2010. p. 9.

43 POSNER, Richard A. When is Parody Fair Use? In: University of Chicago Journal of Legal Studies, v. XXI, p. 67-76, jan. 1992. p. 71.
} 
sua irónica "transcontextualização" e inversão, repetição com diferença. Está implícita uma distanciação crítica entre o texto em fundo a ser parodiado e a nova obra que incorpora, distância geralmente assinalada pela ironia. Mas esta ironia tanto pode ser apenas bem humorada, como pode ser depreciativa; tanto pode ser criticamente construtiva, como pode ser destrutiva ${ }^{44}$.

Não haveria, portanto, no caráter crítico da paródia, a necessidade deste ser direcionado diretamente à obra parodiada, podendo se referir a algo externo ao conteúdo da obra original. A teórica da literatura Camila Alavarce ${ }^{45}$ concorda com o posicionamento de Hutcheon, acrescentando que o texto da paródia só tem sentido se o leitor encontrar neste vestígios do texto parodiado ${ }^{46}$.

Como visto, o conceito e os elementos constitutivos da paródia não são consensualmente estabelecidos na doutrina. A lei, ao não estabelecer uma definição clara do termo para fins do direito autoral, reitera este problema.

Entretanto, a partir deste conjunto de definições expostas, é possível extrair três características predominantes relacionadas à figura: (i) a referência à obra parodiada; (ii) o viés cômico e (iii) o caráter crítico, em alguns casos. Isto, no entanto, é insuficiente para delimitar a figura para fins de uma possível defesa para a produção de fan fiction.

A fim de garantir mais segurança à criação dos fãs, resta olhar para a figura sob a ótica do direito autoral, principalmente acerca das condições estabelecidas pela lei a fim da configuração de paródia como limitação ao direito autoral e compreender como a jurisprudência lida com eventuais litígios envolvendo a produção de paródias.

\subsection{Paródia como limitação ao direito autoral}

Como já estabelecido anteriormente, paródias, por consistirem em recriações de obras preexistentes, são consideradas como obras derivadas ${ }^{47}$. Independentemente disto, a figura

\footnotetext{
${ }^{44}$ HUTCHEON, Linda. Uma Teoria da Paródia: Ensinamentos das Formas de Arte do Século XX. Trad. Teresa Louro Perez. Rio de Janeiro: 70, 1985. p. 48.

${ }^{45}$ ALAVARCE, Camila da Silva. A Ironia e suas Refrações: Um estudo sobre a dissonância na paródia e no riso. São Paulo: UNESP, 2009. p. 69.

${ }^{46}$ Vale dizer que, mesmo entre estudiosos da paródia como gênero literário, não há consenso sobre seu exato significado e elementos constitutivos. No capítulo 3 de sua obra "A Ironia e suas Refrações", Camila Alavarce expõe de forma clara estas diversas interpretações distintas relativas à figura da paródia.

47 Há autores que não consideram paródias como obras derivadas, como José de Oliveira Ascensão, alegando que paródias não podem ser obras derivadas ou transformações da obra originária porque desta compartilham apenas o "tema". Discordamos do posicionamento, uma vez que inúmeras paródias utilizam elementos integrantes da obra originária, como personagens, cenários, estilo e situações. Para fins do presente artigo, portanto, consideramos a figura como obra derivada especificamente por causa de sua
} 
consta na parte de Limitações ao Direito Autoral da LDA, o que significa que independem da autorização do autor para serem produzidas, reproduzidas e compartilhadas. 0 Artigo 47 estabelece: "São livres as paráfrases e paródias que não forem verdadeiras reproduções da obra originária nem the implicarem descrédito"48.

Mesmo não fornecendo a definição exata do que pode ser enquadrado como "paródia", o legislador impôs dois requisitos legais para que determinada obra possa ser encaixada na limitação: (i) ela não pode consistir em reprodução da obra originária; e (ii) ela não pode implicar descrédito à obra originária.

Ambos os aspectos são absolutamente subjetivos. É evidente que as paródias devem utilizar elementos da obra parodiada em sua composição, uma vez que, como visto, a referência à obra originária é elemento constitutivo da figura. Não há como definir, no entanto, o momento em que a referência torna-se "verdadeira reprodução" da obra originária, cabendo ao julgador em eventual litígio avaliar este tipo de configuração.

O segundo requisito é ainda mais abstrato; a paródia não deve implicar descrédito à obra parodiada. Marco Antônio dos Anjos afirma que o “descrédito" apontado no texto da lei refere-se à “desonra, menoscabo ou má reputação para a criação primígena” ${ }^{49}$. Neste sentido, a paródia não estaria protegida pela limitação do artigo 47 se esta consistir em uma espécie de ofensa à obra original.

0 problema deste requisito é evidente: como seria possível estabelecer se uma paródia implicaria descrédito à obra parodiada? Esta é uma questão que gera razoável insegurança jurídica para autores de paródias, principalmente aquelas que são elaboradas com a intenção de ridicularizar a obra da qual derivam.

Neste sentido, após breve pesquisa jurisprudencial no STJ e nos Tribunais de Justiça dos Estados de São Paulo e Rio de Janeiro ${ }^{50}$, aliada à pesquisa realizada nos mesmos tribunais

direta dependência e decorrência de uma obra primígena já existente. ASCENSÃO, José de Oliveira. Direito Autoral. São Paulo: Forense, 1980. p. 19.

48 BRASIL. Lei $n^{\circ}$ 9.610, de 19 de fevereiro de 1998. Altera, atualiza e consolida a legislação sobre direitos autorais e dá outras providências. Diário Oficial da República Federativa do Brasil, Brasília, 20 fev. 1998. Disponível em: <http://www.planalto.gov.br/ccivil_03/leis/L9610.htm>. Acesso em: 10 jan. 2017.

49 ANJOS, Marco Antônio dos. O Humor: Estudo à luz do direito de autor e da personalidade. Tese (Doutorado em Direito). 133 f. Faculdade de Direito, Universidade de São Paulo, 2010. p. 59.

${ }^{50}$ A pesquisa foi realizada nos bancos de dados virtuais disponibilizados nos sites dos Tribunais indicados. Os termos pesquisados foram "paródia" e "direito autoral" (e derivados, como "direito de autor" e "direitos autorais"), sempre em conjunto. Foram escolhidos os Tribunais de Justiça destes Estados para complementar a pesquisa já realizada por Perez, que serviu de baste para esta parte do trabalho. 
FAN FICTION E PARÓDIA: UMA TENTATIVA DE VIABILIZAÇÃO DA PRODUÇÃO DE FÃS EM MEIO À AUSÊNCIA DE REFORMA DA LEI DE DIREITOS AUTORAIS

elaborada por Priscila Perez, observa-se alguns pontos relevantes que não sanam, mas ajudam a esclarecer algumas questões abordadas nesta seção:

(i) Grande parte das decisões define "paródia" como imitação cômica de determinada obra preexistente ${ }^{51}$, apesar de algumas delas apontarem para a possibilidade da existência de paródias não humorísticas, mas que possuam apenas caráter crítico ${ }^{52}$;

(ii) Ao tratar da possibilidade de descrédito à obra, o conceito é ainda vago, mas algumas decisões apontam para a figura da "paródia abusiva", em que a obra em si extrapola sua finalidade crítica ou humorística e passa a ofender ou desrespeitar (e não apenas criticar) diretamente a obra parodiada ou o autor desta ${ }^{53}$. Os requisitos para a configuração de ofensa ou desrespeito, por sua vez, ainda são bastante subjetivos; e

51 “A paródia é definida como sendo uma imitação cômica de uma composição literária, ou seja, de uma imitação que possui efeito cômico, utilizando-se de ironia e de deboche, sendo geralmente parecida com a obra de origem, e quase sempre possuindo sentidos diferentes" BRASIL. Tribunal de Justiça do Estado do Rio de Janeiro. Acórdão que julgou improcedente pedido de danos materiais e morais por violação ao direito autoral. Apelação Cível $n^{\circ}$ 0152937-46.2007.8.19.0001. Relator: Mario Assis Gonçalves. 19 de setembro de

2012. Disponível em: <http://www1.tjrj.jus.br/gedcacheweb/default.aspx?UZIP=1\&GEDID=0004C001ADD61CBEC2F071E6BD F858DD7A1B98C4570B1530\&USER=>. Acesso em: 12 jan. 2017.

(Esta definição é a mesma utilizada na Apelação Cível $n^{\circ}$ 0033449-16.2011.8.19.0209/RJ, Rel. Des. José Carlos Varanda Dos Santos).

52 "A paródia é forma de expressão artística que se caracteriza por assentar em outra obra literária, em cima da qual introduz ideia nova, em geral para provocar humor, embora não necessariamente. (...) em tantos outros exemplos clássicos de paródia encontramos sempre o fato de que o autor inova em cima de uma outra criação, introduzindo fator de perplexidade ou de comicidade; (...)."

BRASIL. Primeira Câmara Cível do Poder Judiciário do Estado do Rio de Janeiro. Sentença que julgou improcedente pedido de retirada de propaganda eleitoral por violação ao direito autoral. Agravo de Instrumento $\mathrm{n}^{\circ}$ 09901/2000. Relatora: Maria Augusta Vaz Monteiro de Figueiredo. 29 de agosto de 2000. Disponível em: <https://tj-rj.jusbrasil.com.br/jurisprudencia/425482480/agravo-de-instrumento-ai161332120008190000 -rio-de-janeiro-capital-9-vara-civel/inteiro-teor-425482489?ref=juris-tabs> . Acesso em: 12 jan. 2017.

"A proximidade entre o figurino das personagens, o público alvo visado, o tema central do enredo e a descrição da peça teatral afastam, ao menos neste momento processual, qualquer indício caracterizador da paródia. Não se vislumbram, de prontidão, elementos de ironia, de desconstrução da ideia anterior para uma reanálise satírica da personagem ou da narrativa." (grifos nossos).

BRASIL. Tribunal de Justiça do Estado São Paulo. Acórdão que negou provimento ao pedido de suspensão de peça teatral por violação ao direito autoral. Agravo de Instrumento $\mathrm{n}^{\circ}$ 207658540.2015.8.26.0000 . Relator: Fabio Henrique Podestá. 11 de setembro de 2015. Disponível em: <https://tj-sp.jusbrasil.com.br/jurisprudencia/233397380/agravo-de-instrumento-ai-

20765854020158260000-sp-2076585-4020158260000/inteiro-teor-233397399?ref=juris-tabs >. Acesso em: 12 jan. 2017.

53 “(...) Na hipótese em tela, não há que se falar em paródia abusiva. Com efeito, o intuito cômico da matéria é patente, tendo em vista estar localizada na coluna denominada "Esporte, humor e irreverência" e ironizar a participação de um atleta brasileiro nas olimpíadas. (...)" (grifos nossos).

BRASIL. Tribunal de Justiça do Estado do Rio de Janeiro. Acórdão que negou provimento ao pedido de danos morais por violação ao direito autoral. Apelação $n^{\circ} 0415440-85.2008$.8.19.0001. Relatora: Renata Machado Costa. 5 de fevereiro de 2014. Disponível em: <http://www1.tjrj.jus.br/gedcacheweb/default.aspx?UZIP=1\&GEDID=0004EBDB5EDC53D6154F30156BC5E1 
(iii) Curiosamente, como apontado por Perez ${ }^{54}$, existe ainda uma condição não prevista na legislação que é amplamente levada em consideração nos tribunais: a finalidade comercial. A limitação prevista no Art. 47 da LDA em nenhum momento exige que as paródias não possuam finalidade comercial. No entanto, tribunais consideram a ausência de fins lucrativos um elemento relevante para afastar a ofensa aos direitos autorais e enquadrar a obra na limitação relativa às paródias ${ }^{55}$.

Ainda que muitos elementos que compõem a figura da paródia sejam demasiadamente subjetivos, a partir desta análise foi possível identificar alguns pontos que são levados em consideração na tutela da limitação: (i) o caráter cômico, predominantemente considerado como característica principal da paródia; (ii) a não ofensa ou desrespeito à obra originária e seu autor; e (iii) a ausência de finalidade lucrativa ou comercial. O caráter crítico da paródia é esparsamente considerado pela jurisprudência, mas ainda não são claros os elementos que tornam uma crítica a determinada obra ofensiva a esta.

Com todo este arcabouço conceitual em mente, resta apenas verificar se há algum tipo de fan fiction que poderia ser enquadrada na limitação do artigo 47 da LDA.

CBF2F7C502621A372C>. Acesso em: 13 jan. 2017.

Neste sentido, ver também a Apelação Cível 8169/2006/RJ, Rel. Des. Ronald Valladares.

${ }^{54}$ PEREZ, Priscila de Carvalho Ruiz. Paródia como Violação de Direito Autoral. In: Revista da ABPI, v. 137, 2015. Disponível em: <http://prisciladecarvalhoperez.jusbrasil.com.br/artigos/240522892/parodia-como-violacao-de-direitoautoral>. Acesso em: 6 set. 2016.

55 “Acrescenta que a Lei de Direitos Autorais, quando autoriza a paródia e a paráfrase, não o faz para permitir uso comercial de obras artísticas, mas sim para fins de estudo, crítica ou polêmica, nos quais se evidencia o nome do autor e a obra original".

BRASIL. Superior Tribunal de Justiça. Acórdão que negou provimento ao pedido de suspensão de propaganda televisiva, danos morais e patrimoniais por violação ao direito autoral. Recurso Especial $n^{\circ}$ 1131498/RJ. Relator: Raul Araújo. 17 de maio de 2011. Disponível em: <https://stj.jusbrasil.com.br/jurisprudencia/21119962/recurso-especial-resp-1131498-rj-2009-0149030-4stj?ref=juris-tabs $>$. Acesso em: 13 jan. 2017.

“(...)A reprodução das composições musicais não foi o objetivo do comercial, não prejudicou sua exploração normal e sequer causou prejuízo à autora, no tocante aos direitos materiais de exploração(....)".

BRASIL. Tribunal de Justiça do Estado São Paulo. Acórdão que negou provimento ao pedido de suspensão de propaganda televisiva, danos morais e patrimoniais por violação ao direito autoral. Apelação Cível $\mathrm{n}^{\circ}$ 480.378-4/0-00. Relator: Carlos Stroppa. 10 de junho de 2008. Disponível em: <https: / / esaj.tjsp.jus.br/cjsg/getArquivo.do;jsessionid=08236BB3DA76C2B1EF9E0E8043EADBF0.cjsg1? cdAcordao=2677849\&cdForo=0\&vlCaptcha=jjbsf $>$. Acesso em: 12 jan. 2017. 


\section{FAN FICTION PODE SER CONSIDERADA PARÓDIA?}

A ideia de invocar a figura da paródia como forma de evitar a responsabilização de autores de fan fiction por violação ao direito autoral é amplamente presente em análises estadunidenses sobre o tema ${ }^{56}$, e isto ocorre por causa das especificidades do sistema de direitos autorais norte-americano, principalmente com relação às limitações ao direito autoral.

Ao contrário do sistema normativo brasileiro, em que as limitações ao direito autoral são expressamente definidas em um rol exaustivo de situações previstas na lei, o sistema estadunidense adota uma cláusula aberta para estabelecer quais seriam as situações em que a utilização de determinada obra preexistente independe da autorização do detentor dos direitos autorais. Este sistema é chamado de fair use ${ }^{57}$. Neste sistema, a construção jurisprudencial é absolutamente essencial para garantir segurança jurídica a determinadas formas de manifestação cultural que utilizam-se de obras preexistentes.

Como bem aponta Natalie Montano, a paródia é uma figura razoavelmente consolidada na jurisprudência estadunidense como hipótese de fair use, por isto ela é evocada com frequência em dissídios envolvendo obras derivadas neste contexto ${ }^{58}$. A defesa da paródia foi utilizada em dois grandes casos envolvendo obras que, apesar de não serem especificamente fan fiction, assemelham-se muito a estas em sua estrutura.

\footnotetext{
${ }^{56}$ Neste sentido, ver: MONTANO, Natalie. Hero with a Thousand Copyright Violations: Modern Myth and an Argument for Universally Transformative Fan Fiction. In: Northwestern Journal of Technology and Intellectual Property, v. 11, n. 7, p. 689-705, 2013.

STROUDE, Rachel L. Complimentary Creation: Protecting Fan Fiction as Fair Use. In: Marquette Intellectual Property Law Review, v. 14, n. 1, p. 191-213, 2010.

LEWIS, Lauren; BLACK, Rebecca; TOMLINSON, Bill. Let Everyone Play: An Educational Perspective on Why Fan Fiction Is, or Should Be, Legal. In: International Journal of Learning and Media, Cambridge, v. 1, n. 1, p. 67-81, 2009.

BECKER, Jane M. Stories Around the Digital Campfire: Fan Fiction and Copyright Law in the Age of the Internet. In: Connectitcul Public Interest Law Journal, v. 14, n. 1, p. 133-154, 2014.

57 Tomando como exemplo a lei estadunidense, onde há razoável número de dissídios envolvendo fan fiction, a cláusula de fair use está prevista no US Code \$7, e prescreve que quatro fatores devem ser levados em consideração pelo judiciário para determinar se determinada utilização pode ser considerada "justa” ou não, são eles: (1) a finalidade da utilização, levando em consideração se a utilização é comercial ou não comercial ou se tem fins educacionais; (2) a natureza da obra protegida, incluindo-se aqui se a obra é ficção ou não-ficção; (3) a quantidade e substancialidade da obra que é utilizada na obra derivada; e (4) o impacto ou efeito da utilização no mercado ou no valor da obra original. Estas diretrizes são utilizadas pelos tribunais para decidir se determinada utilização pode ser encarada ou não como limitação ao direito autoral.

${ }^{58}$ MONTANO, Natalie. Hero with a Thousand Copyright Violations: Modern Myth and an Argument for Universally Transformative Fan Fiction. In: Northwestern Journal of Technology and Intellectual Property, v. 11, n. 7, p. 689-705, 2013. p. 692.
} 
0 primeiro caso $^{59}$, julgado em 2001, envolveu um romance chamado The Wind Done Gone, escrito pela autora americana Alice Randall. Ainda que consistisse em um livro comercialmente disponível, a obra buscava recontar a história de “...E o Vento Levou” sob a perspectiva de uma escrava (a obra original era narrada sob a perspectiva dos donos de escravos). Na narrativa, a autora criticava e satirizava diversos elementos considerados racistas do romance original.

A corte decidiu que, apesar da utilização dos mesmos personagens, cenários e períodos narrados nas obras indicadas, The Wind Done Gone possuía elementos críticos e satíricos que enquadrariam a obra como paródia, afastando a necessidade de autorização dos detentores dos direitos de “...E O Vento Levou”, apesar de sua finalidade comercial ${ }^{60}$.

Por outro lado, não é todo e qualquer tipo de paródia que pode ser abarcada na doutrina do fair use. No caso Salinger v. Colting ${ }^{61}$, julgado em 2010, Frederik Colting escreveu 60 Years Later, um livro que buscava retratar a vida do personagem Holden Caulfield, protagonista de "O Apanhador no Campo de Centeio" 60 anos após os acontecimentos deste. A 2nd Circuit Court of Appeals estadunidense afastou a possibilidade de enquadramento desta obra como paródia, condenando Colting por violação ao direito autoral.

Ainda que o direito brasileiro inclua em seu rol de limitações ao direito autoral a figura da paródia sem estabelecer os critérios para sua configuração, os elementos analisados na seção anterior podem ajudar a compreender quais seriam os tipos de fan fiction passíveis de serem enquadradas conceitualmente como paródias e, em seguida, enquadradas na limitação prevista no art. 47 da LDA.

\footnotetext{
59 UNITED STATES COURT OF APPEAL. Suntrust Bank v. Houghton Mifflin Company (11th Cir.). 10 out. 2001. Disponível em: <https://scholar.google.com/scholar_case?case=13094222792307527660>. Acesso em: 5 set. 2016.

60 “ (....) the district court erred by finding that the critical or parodic element of The Wind Done Gone is anything but clear-cut. Far from amounting to "unabated piracy"(...) The Wind Done Gone is unequivocally parody, as both Judge Birch and the Supreme Court in Campbell v. Acuff-Rose Music, Inc., 510 U.S. 569, 114 S.Ct. 1164, 127 L.Ed.2d 500 (1994), define that term. Indeed, the book is critical by constitution, its main aim being to shatter Gone With the Wind's window on life in the antebellum and Civil War South. Second, in service of this parodic design, Randall radically reshapes what she borrows from Mitchell." UNITED STATES COURT OF APPEAL. Suntrust Bank v. Houghton Mifflin Company (11th Cir.). 10 out. 2001. Disponível em: <https://scholar.google.com/scholar_case?case $=13094222792307527660>$. Acesso em: 5 set. 2016.

61 UNITED STATES COURT OF APPEAL. Salinger v. Colting (2 ${ }^{\text {nd }}$ Cir $) .30$ abr. 2010. Disponível em: <https://cyber.harvard.edu/people/tfisher/IP/2010\%20Salinger\%20Abridged.pdf>. Acesso em: 6 set. 2016.
} 


\subsection{Categorias que podem se encaixar na limitação}

Como visto, a maior parte dos estudiosos de direito autoral e a jurisprudência insistem em reconhecer a paródia como uma espécie de imitação cômica de uma obra preexistente. Neste sentido, obras de fan fiction de comédia que visassem expor os personagens da obra original a situações cômicas ou ao ridículo poderiam muito bem enquadrar-se na limitação.

Por exemplo, uma história em que os personagens de 0 Senhor dos Anéis são transportados para o Rio de Janeiro na atualidade e têm de lidar com a realidade brasileira de maneira cômica. Expor estas personagens ao ridículo contribuiria para sua adequação à figura da paródia.

Quanto aos requisitos definidos pelo artigo 47, a própria lógica da produção de fãs já é suficiente para respeitá-los. Como a fan fiction constrói-se pela apropriação de personagens e cenários de obras preexistentes para a criação de histórias inteiramente novas, não há o que discutir em relação à configuração de "verdadeira reprodução" da obra original.

Com relação ao segundo elemento, é complicado falar em descrédito à obra original no contexto da cultura de fãs. A própria ideia de fan fiction parte do pressuposto de que o fã cria a sua história pela reverência e amor à obra original. Seria muito difícil alegar que uma fan fiction de comédia teria o objetivo de diminuir o valor da obra original ou de seu autor.

Por fim, há ainda o elemento jurisprudencial de configuração de paródia: a ausência de finalidade comercial. Esta é a mais simples: obras de fan fiction, quase sem exceção, são livremente e gratuitamente disponibilizadas entre os fãs, não tendo quaisquer intenções comerciais ou de lucro. Fan fiction humorística, portanto, tem grandes chances de estar abarcada pela limitação do art. 47.

\subsection{Categorias que provavelmente não se encaixam na limitação}

Por mais que existam teóricos que afirmem que uma paródia não necessariamente deve ser crítica ou cômica, bastando a modificação transformativa da obra e sua conseguinte "transcontextualização" 62 , estudiosos do direito autoral e a jurisprudência indicam que é necessário a existência de ao menos um destes elementos (predominantemente o caráter

62 HUTCHEON, Linda. Uma Teoria da Paródia: Ensinamentos das Formas de Arte do Século XX. Trad. Teresa Louro Perez. Rio de Janeiro: 70, 1985. 
ISSN 1981-3694

(DOI): $10.5902 / 1981369427444$

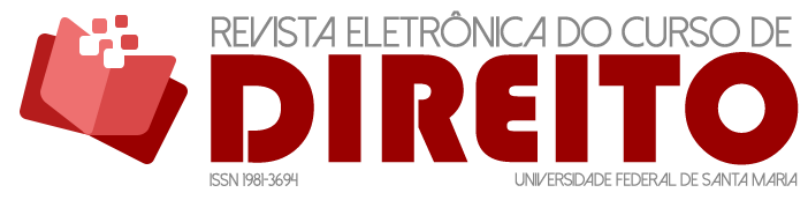

FAN FICTION E PARÓDIA: UMA TENTATIVA DE VIABILIZAÇÃO DA PRODUÇ̃̃O DE FÃS EM MEIO À AUSÊNCIA DE REFORMA DA LEI DE DIREITOS AUTORAIS

ANA PAULA CAMELO CARLOS AUGUSTO LIGUORI FILHO

cômico) para sua configuração. Neste sentido, ausentes ambas estas características, muito dificilmente uma fan fiction poderia ser considerada paródia.

Partindo do pressuposto de que a história poderia se enquadrar no conceito de paródia, as questões são outras. Ainda que seja complicado considerar fan fiction como "verdadeira reprodução" da obra original, o requisito da não implicação de descrédito é algo que pode muito bem ser alegado em relação a determinadas histórias para afastar a aplicação do art. 47, mesmo que ela contenha elementos que a caracterizem como paródia.

Como mencionado anteriormente, um gênero muito popular de fan fiction são as histórias eróticas. Apesar da popularidade, muitas destas histórias utilizam personagens de narrativas infanto-juvenis, como Harry Potter e Desventuras em Série. Neste sentido, é bem provável que autores e/ou detentores de direitos autorais aleguem que a história derivada implicaria descrédito à obra original, independentemente de sua configuração como paródia ou não.

Exemplo disto é J. K. Rowling, autora da série Harry Potter. Ela incentiva e se sente lisonjeada com a produção de histórias do personagem por fãs, apenas não admite que tais histórias tenham fins lucrativos e reitera que "os livros são destinados a jovens leitores, (...) se uma criança se deparar com um conto sobre Harry Potter para maiores de 18 anos, isso seria um grande problema"63.

A jurisprudência, independentemente de qualquer juízo de valor, identifica que um dos elementos que caracterizaria o descrédito à obra originária seria sua representação de forma “vulgar" 64 . Dito isto, seria complicado enquadrar fan fiction erótica, derivada de obras para o público jovem ${ }^{65}$, na limitação do artigo 47.

Para além da alegação de que as histórias implicariam em descrédito à obra original, é bem possível que autores destas obras aleguem também que a fan fiction erótica viola seus direitos morais, principalmente o disposto no inciso IV do artigo 24:

63 WATERS, Darren. Rowling backs Potter fan fiction. BBC, 27 maio 2004. Disponível em: <http://news.bbc.co.uk/2/hi/entertainment/3753001.stm>. Acesso em: 6 set. 2016.

${ }^{64}$ Apelação Cível no 8169/2006, Rel. Des. Ronald Valladares: "Ao contrário do sustentado pelo recorrente réu, não lhe socorre a regra contida no art. 47 da lei Autoral, pois enquadram-se nessa previsão legal as reproduções que não tragam nenhuma forma depreciativa à obra principal. Trocar o título "dona flor" por "dona frô" e "seus dois maridos" por "mais seus dois nego", ultrapassa o limite da irreverência e do cômico e passa a caracterizar uma forma vulgar e mesmo irreverente de tratar o título de uma obra da literatura(...)" (grifos nossos).

${ }^{65}$ Questiona-se até que ponto uma fan fiction erótica poderia ser considerada descrédito à obra original se esta fosse baseada em uma história também erótica, como 50 Tons de Cinza. Limita-se aos exemplos infanto-juvenis para ilustrar com mais clareza a questão. 
Art. 24. São direitos morais do autor:

[...]

IV - o de assegurar a integridade da obra, opondo-se a quaisquer modificações ou à prática de atos que, de qualquer forma, possam prejudicá-la ou atingi-lo, como autor, em sua reputação ou honra;

Um autor ou autora de obras infanto-juvenis poderia evocar este direito para evitar a vinculação de sua bibliografia e seu nome a uma obra erótica voltada a um público que não o de suas obras originais.

\subsection{Zona cinzenta: fan fiction como crítica à obra original}

Uma categoria de fan fiction cujo enquadramento na limitação prevista no art. 47 seria mais complexo e controverso são aquelas histórias cujo objetivo é criticar a obra original sem quaisquer pretensões cômicas ou humorísticas. Como já apontado anteriormente, as histórias de “Mary Sue" são um exemplo característico desta questão.

0 grande problema com relação a este tipo de fan fiction seria seu enquadramento conceitual como paródia. Histórias de "Mary Sue" nem sempre têm a intenção de ridicularizar ou realizar uma imitação cômica das obras originais, o que afastaria sua categorização como paródia por uma parte dos estudiosos de direito autoral ${ }^{66}$ e pela jurisprudência, como visto anteriormente.

Por outro lado, para outros ${ }^{67}$, a mera intenção crítica à obra original já bastaria para a configuração de paródia, o que viabilizaria o seu enquadramento na limitação do artigo 47. Esta

${ }^{66}$ CHAGARES, Michael. Parody or Piracy: The Protective Scope of the Fair Use Defense to Copyright Infringement Actions Regardinf Parodies. In: Columbia-VLA Journal of Law \& the Arts, v. 12, p. 229-248, 1988. p. 229.

ABRÃO, Eliane Y. Direitos de Autor e Direitos Conexos. 2. ed. São Paulo: Migalhas, 2014. p. 357;

PEREZ, Priscila de Carvalho Ruiz. Paródia como Violação de Direito Autoral. In: Revista da ABPI, v. 137, jul./ago. 2015. Disponível em: <http://prisciladecarvalhoperez.jusbrasil.com.br/artigos/240522892/parodia-como-violacao-de-direitoautoral>. Acesso em: 6 set. 2016.

${ }^{67}$ ASCENSÃO, José de Oliveira. Direito Autoral. São Paulo: Forense, 1980. p. 19.

ANJOS, Marco Antônio dos. O Humor: Estudo à luz do direito de autor e da personalidade. Tese (Doutorado em Direito). 133 f. Faculdade de Direito, Universidade de São Paulo, 2010. p. 9.

FRAGOSO, João Henrique da Rocha. Direito Autoral: Da Antiguidade à Internet. São Paulo: Lumen luris, 2009. p. 327. 
caracterização seria ainda corroborada ainda por estudiosos de literatura e cultura ${ }^{68}$ e parte da jurisprudência.

Neste sentido, por causa desta incerteza conceitual, fãs autores de histórias de "Mary Sue" estariam em um cenário de insegurança jurídica quanto à legalidade de suas produções culturais. Algo que, como visto, pode muito bem coibir uma prática substancial no empoderamento de jovens fãs que não se sentem representados pelas histórias que idolatram.

\section{CONCLUSÃO}

A elaboração e compartilhamento de fan fiction são práticas amadoras, sem finalidade comercial e característica de um universo em que fãs querem exprimir seu amor a determinados romances, filmes e séries de TV. Tomando emprestado elementos como personagens e cenários destas obras, estes fãs podem criar suas próprias histórias e compartilhá-las entre outras pessoas que compartilham o mesmo interesse.

Apesar disto, com base na legislação autoral brasileira, a utilização de obras ou elementos de obras protegidas sem autorização do titular consiste em violação ao direito autoral. As utilizações que não necessitam desta autorização estão previstas nos artigos 46, 47 e 48 da Lei $n^{\circ}$ 9.610/98.

De forma a tentar viabilizar a produção amadora de fãs no cenário contemporâneo, este artigo buscou identificar se a prática de elaboração de fan fiction poderia se encaixar na limitação ao direito autoral prevista no artigo 47 da LDA, que permite a produção livre de paródias sem autorização do detentor de direitos autorais, conquanto esta não seja verdadeira cópia da obra original ou implique descrédito àquela.

O grande problema desta limitação reside na própria incerteza sobre o que poderia ou não ser considerado paródia, uma vez que a lei não estabelece os requisitos para que determinada obra enquadre-se como uma. Neste sentido mais ou menos categorias de fan fiction poderiam se enquadrar na limitação do artigo 47 a depender dos diferentes conceitos de "paródia" adotados, seja com relação à necessidade desta possuir finalidade humorística ou se seu eventual caráter crítico à obra parodiada já é suficiente para a configuração.

\footnotetext{
${ }^{68}$ ALAVARCE, Camila da Silva. A Ironia e suas Refrações: Um estudo sobre a dissonância na paródia e no riso. São Paulo: UNESP, 2009. e HUTCHEON, Linda. Uma Teoria da Paródia: Ensinamentos das Formas de Arte do Século XX. Trad. Teresa Louro Perez. Rio de Janeiro: 70, 1985.
} 
De forma geral, o ideal para a manutenção e propagação da cultura de fãs como um todo seria uma possível reforma no rol de limitações ao direito autoral, de preferência com a inclusão de uma limitação que viabilizasse a produção de obras derivadas amadoras sem finalidade comercial ou lucrativa. No entanto, na ausência de uma reforma legislativa, a maior parte destes autores situa-se em um complicado cenário de insegurança jurídica e a lei autoral, elaborada para estimular a criação cultural, acaba neste caso prejudicando-a.

\section{REFERÊNCIAS}

ABRÃO, Eliane Y. Direitos de Autor e Direitos Conexos. 2. ed. São Paulo: Migalhas, 2014.

ALAVARCE, Camila da Silva. A Ironia e suas Refrações: Um estudo sobre a dissonância na paródia e no riso. São Paulo: UNESP, 2009.

ANJOS, Marco Antônio dos. O Humor: Estudo à luz do direito de autor e da personalidade. Tese (Doutorado em Direito). 133 f. Faculdade de Direito, Universidade de São Paulo, 2010.

ASCENSÃO, José de Oliveira. Direito Autoral. São Paulo: Forense, 1980.

BECKER, Jane M. Stories Around the Digital Campfire: Fan Fiction and Copyright Law in the Age of the Internet. In: Connectitcul Public Interest Law Journal, v. 14, n. 1, p. 133-154, 2014.

BRASIL. Lei $n^{\circ}$ 9.610, de 19 de fevereiro de 1998. Altera, atualiza e consolida a legislação sobre direitos autorais e dá outras providências. Diário Oficial da República Federativa do Brasil, Brasília, 20 fev. 1998. Disponível em: <http://www.planalto.gov.br/ccivil_03/leis/L9610.htm>. Acesso em: 10 jan. 2017.

BRASIL. Primeira Câmara Cível do Poder Judiciário do Estado do Rio de Janeiro. Sentença que julgou improcedente pedido de retirada de propaganda eleitoral por violação ao direito autoral. Agravo de Instrumento $n^{\circ}$ 09901/2000. Relatora: Maria Augusta Vaz Monteiro de Figueiredo. 29 de agosto de 2000. Disponível em: <https://tj-

rj.jusbrasil.com.br/jurisprudencia/425482480/agravo-de-instrumento-ai-161332120008190000rio-de-janeiro-capital-9-vara-civel/inteiro-teor-425482489?ref=juris-tabs> . Acesso em: 12 jan. 2017.

BRASIL. Tribunal de Justiça do Estado do Rio de Janeiro. Acórdão que julgou improcedente pedido de danos materiais e morais por violação ao direito autoral. Apelação Cível $\mathrm{n}^{\circ}$ 0152937-46.2007.8.19.0001. Relator: Mario Assis Gonçalves. 19 de setembro de 2012. Disponível em: <http://www1.tjrj.jus.br/gedcacheweb/default.aspx?UZIP=1\&GEDID=0004C001ADD61CBEC2 F071E6BDF858DD7A1B98C4570B1530\&USER=>. Acesso em: 12 jan. 2017.

BRASIL. Tribunal de Justiça do Estado do Rio de Janeiro. Acórdão que julgou improcedente pedido de indenização por violação ao direito autoral. Apelação Cível nº 0033449- 
16.2011.8.9.0209. Relator: José Carlos Varanda dos Santos. 18 de agosto de 2015. Disponível em: <https://tj-rj.jusbrasil.com.br/jurisprudencia/359507557/apelacao-apl-

334491620118190209-rio-de-janeiro-barra-da-tijuca-regional-4-vara-civel/inteiro-teor359507565?ref=juris-tabs>. Acesso em: 12 jan. 2017.

BRASIL. Tribunal de Justiça do Estado do Rio de Janeiro. Acórdão que negou provimento ao pedido de danos morais por violação ao direito autoral. Apelação $n^{\circ} 0415440$ -

85.2008.8.19.0001. Relatora: Renata Machado Costa. 5 de fevereiro de 2014. Disponível em:

<http: / / www1.tjrj.jus.br/gedcacheweb/default. aspx?UZIP=1\&GEDID=0004EBDB5EDC53D6154F30 156BC5E1CBF2F7C502621A372C>. Acesso em: 13 jan. 2017.

BRASIL. Tribunal de Justiça do Estado São Paulo. Acórdão que negou provimento ao pedido de suspensão de peça teatral por violação ao direito autoral. Agravo de Instrumento $n^{\circ} 2076585$ 40.2015.8.26.0000 . Relator: Fabio Henrique Podestá. 11 de setembro de 2015. Disponível em: <https://tj-sp.jusbrasil.com.br/jurisprudencia/233397380/agravo-de-instrumento-ai20765854020158260000-sp-2076585-4020158260000/inteiro-teor-233397399?ref $=$ juris-tabs $>$. Acesso em: 12 jan. 2017.

BRASIL. Tribunal de Justiça do Estado São Paulo. Acórdão que negou provimento ao pedido de suspensão de propaganda televisiva, danos morais e patrimoniais por violação ao direito autoral. Apelação Cível $n^{\circ}$ 480.378-4/0-00. Relator: Carlos Stroppa. 10 de junho de 2008. Disponível

em: <https: / / esaj.tjsp.jus.br/cjsg/getArquivo.do;jsessionid=08236BB3DA76C2B1EF9E0E8043EAD BF0.cjsg1?cdAcordao=2677849\&cdForo=0\&vlCaptcha=jjbsf>. Acesso em: 12 jan. 2017.

BRASIL. Superior Tribunal de Justiça. Acórdão que negou provimento ao pedido de suspensão de propaganda televisiva, danos morais e patrimoniais por violação ao direito autoral. Recurso Especial n 1131498/RJ. Relator: Raul Araújo. 17 de maio de 2011. Disponível em: <https://stj.jusbrasil.com.br/jurisprudencia/21119962/recurso-especial-resp-1131498-rj-20090149030-4-stj?ref=juris-tabs>. Acesso em: 13 jan. 2017.

CHAGARES, Michael. Parody or Piracy: The Protective Scope of the Fair Use Defense to Copyright Infringement Actions Regardinf Parodies. In: Columbia-VLA Journal of Law \& the Arts, v. 12, p. 229-248, 1988.

CHANDER, Anupam; SUNDER, Madhavi. Everyone's a Superhero: A Cultural Theory of "Mary Sue" Fan Fiction as Fair Use. In: California Law Review, v. 95, p. 597-626, 2007. Disponível em: <http: / / scholarship.law. berkeley.edu/cgi/viewcontent.cgi?article=1228\&context=californialawr eview>. Acesso em: 6 set. 2016.

CIANFAGLIONE, Natalia. Hollywood Online: Fan Fiction, Copyright and the Internet. Boston University School of Law, 2011. Disponível em:

<http://papers.ssrn.com/sol3/papers.cfm?abstract_id=2094179>. Acesso em: 5 set. 2016.

FERREIRA, Aurélio B. H. Aurélio século XXI: o dicionário da Língua Portuguesa. 3. ed. Rio de Janeiro: Nova Fronteira, 1999.

FRAGOSO, João Henrique da Rocha. Direito Autoral: Da Antiguidade à Internet. São Paulo: Lumen luris, 2009. 
GENRE. Fanlore, 27 jul. 2017. Disponível em: <https://fanlore.org/wiki/Genre>. Acesso em: 31 ago. 2016.

HELLEKSON, Helen; BUSSE, Kristina (Org.). Fan Fiction and Fan Communities in the Age of the Internet: New Essays. Jefferson: McFarland, 2006. Versão Kindle.

HOUAISS, Antônio. Dicionário Houaiss da Língua Portuguesa. Rio de Janeiro: Objetiva, 2012.

HUTCHEON, Linda. Uma Teoria da Paródia: Ensinamentos das Formas de Arte do Século XX. Trad. Teresa Louro Perez. Rio de Janeiro: 70, 1985.

LEWIS, Lauren; BLACK, Rebecca; TOMLINSON, Bill. Let Everyone Play: An Educational Perspective on Why Fan Fiction Is, or Should Be, Legal. In: International Journal of Learning and Media, Cambridge, v. 1, n. 1, p. 67-81, 2009.

MAYER-SCHÖNBERGER, Viktor; WONG, Lena. Fan or Foe? Fan Fiction, Authorship, and the Fight for Control. In: IDEA - The Intellectual Property Law Review, v. 54, n. 1, 2013.

MIZUKAMI, Pedro; LEMOS, Ronaldo; MAGRANI, Bruno; SOUZA, Carlos Affonso Pereira de. Exceptions and Limitations to Copyright in Brazil: A Call for Reform. In: SHAVER, Lea. Access to Knowledge in Brazil: New Research on Intellectual Property, Innovation and Development. New Haven: Information Society Project, 2010. p. 67-122.

MONTANO, Natalie. Hero with a Thousand Copyright Violations: Modern Myth and an Argument for Universally Transformative Fan Fiction. In: Northwestern Journal of Technology and Intellectual Property, v. 11, n. 7, p. 689-705, 2013.

O QUE é um beta beader? Nyah! Fanfiction, 21 set. 2017. Disponível em: <https://fanfiction.com.br/pagina/30/0_que_e_um_beta_reader/>. Acesso em: 30 ago. 2016.

PEREZ, Priscila de Carvalho Ruiz. Paródia como Violação de Direito Autoral. In: Revista da ABPI, v. 137, jul./ago. 2015. Disponível em:

<http: / / prisciladecarvalhoperez.jusbrasil.com.br/artigos/240522892/parodia-como-violacao-dedireito-autoral>. Acesso em: 6 set. 2016.

POSNER, Richard A. When is Parody Fair Use? In: University of Chicago Journal of Legal Studies, v. XXI, p. 67-76, jan. 1992.

SCHWABACH, Aaron. Fan Fiction and Copyright: Outsider Works and Intellectual Property Protection. Farnham: Ashgate, 2011. Versão Kindle.

SENDLOR, Charles. Fan Fiction Demographics in 2010: Age, Sex, Country. 18 mar. 2011. Disponível em: <http://ffnresearch.blogspot.com.br/2011/03/fan-fiction-demographics-in-2010age.html>. Acesso em: 30 ago. 2016.

SPOCKANALIA. Fanlore, 14 abr. 2018. Disponível em: <https://fanlore.org/wiki/Spockanalia> . Acesso em: 20 abr. 2018. 
ISSN 1981-3694

(DOI): $10.5902 / 1981369427444$

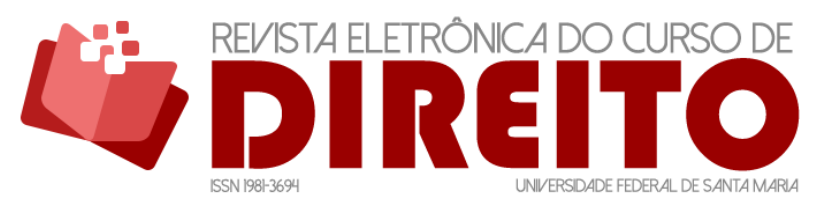

FAN FICTION E PARÓDIA: UMA TENTATIVA DE VIABILIZACC̃̃O DA PRODUÇ̃̃O DE FÃS EM MEIO À AUSÊNCIA DE REFORMA DA LEI DE DIREITOS AUTORAIS

AnA PAUla CAMELO CARLOS AUGUSTO LIGUORI FILHO

STROUDE, Rachel L. Complimentary Creation: Protecting Fan Fiction as Fair Use. In: Marquette Intellectual Property Law Review, v. 14, n. 1, p. 191-213, 2010.

TUSHNET, Rebecca. Legal Fictions: Copyright, Fan Fiction and a New Common Law. In: Loyola of Los Angeles Entertainment Journal, v. 17, n. 3, p. 651-686, 1997.

UNITED STATES COURT OF APPEAL. Salinger v. Colting ( $2^{\text {nd }}$ Cir). 30 abr. 2010. Disponível em: <https: / / cyber.harvard.edu/people/tfisher/IP/2010\%20Salinger\%20Abridged.pdf>. Acesso em: 6 set. 2016.

UNITED STATES COURT OF APPEAL. Suntrust Bank v. Houghton Mifflin Company (11th Cir.). 10 out. 2001. Disponível em:

<https: //scholar.google.com/scholar_case?case $=13094222792307527660$ >. Acesso em: 5 set. 2016.

WATERS, Darren. Rowling backs Potter fan fiction. BBC, 27 maio 2004. Disponível em: <http://news.bbc.co.uk/2/hi/entertainment/3753001.stm>. Acesso em: 6 set. 2016.

Recebido em: 31.05.2017 / Revisões requeridas em: 20.12.2017 / Aprovado em: 05.02.2018 / Publicado em: 05.05.2018

\section{COMO FAZER A REFERÊNCIA DO ARTIGO (ABNT):}

CAMELO, Ana Paula; LIGUORI FILHO, Carlos Augusto. Fan fiction e paródia: uma tentativa de viabilização da produção de fãs em meio a ausência de reforma da lei de direitos autorais. Revista Eletrônica do Curso de Direito da UFSM, Santa Maria, RS, v. 13, n. 1, p. 20-48, abr. 2018. ISSN 1981-3694. Disponível em: <

https://periodicos.ufsm.br/revistadireito/article/view/27444 >. Acesso em: dia mês. ano. doi: http://dx.doi.org/10.5902/1981369427444 . 